\title{
Histone H4 N-Terminal Acetylation in Kasumi-1 Cells Treated with Depsipeptide Determined by Acetic Acid-Urea olyacrylamide Gel Electrophoresis, Amino Acid Coded Mass Tagging, and Mass
}

\section{Spectrometry}

\author{
Liwen Zhang ${ }^{\dagger}$, Xiaodan Su $\ddagger$, Shujun Liu§, Amy R. Knapp $\|$, Mark R. Parthun $\|$, Guido \\ Marcucci $\S$, and Michael A. Freitas ${ }^{\star}, \perp$ \\ Mass Spectrometry and Proteomics Facility, Campus Chemical Instrument Center, Department of \\ Chemistry, Division of Hematology/Oncology, Department of Molecular and Cellular Biochemistry, \\ and Human Cancer Genetics, Department of Molecular Immunology Virology and Medical Genetics, \\ Comprehensive Cancer Center, The Ohio State University, Columbus, Ohio 43210
}

\section{Abstract}

Disrupted patterns of acetylation and deacetylation of core histones play an important role in silencing transcription of hematopoietic important genes in acute myeloid leukemia (AML). A thorough investigation of these mechanisms and the response to pharmacologic modifiers will provide a better understanding of the role of histone acetylation in leukemogenesis. We describe here an analytical approach that combines acid urea polyacrylamide gel electrophoresis (AU-PAGE), amino acid coded mass tagging (AACM), and mass spectrometry (MS) for the investigation of histone acetylation patterns. The combined approach was used to follow the dynamics of $\mathrm{H} 4$ acetylation in Kasumi-1 cells harboring the fusion gene AML1/ETO shown to aberrantly recruit histone deacetylases (HDACs). The histones in Kasumi-1 cells were labeled by growing the cells in media in which lysine was replaced with stable isotope-labeled lysine $\left(\right.$ Lys- $\left.\mathrm{D}_{4}\right)$. Labeled and unlabeled cells were treated with depsipeptide and analyzed at different time points $(0,4,8,12,24$, and $48 \mathrm{~h})$. The cells were mixed, the histone was extracted, and acetylated $\mathrm{H} 4$ isoforms were separated using AU-PAGE before in-gel trypsin digestion. The digests were analyzed by MALDI-TOF MS. Peptides were identified by mass and isotope pattern. LC-MS/MS of Arg-C digests were also performed to verify the acetylation pattern for $\mathrm{H} 4$. The major pattern of acetylation was determined as follows: initial acetylation at K16, followed by acetylation at $\mathrm{K} 12$, and finally acetylation of either $\mathrm{K} 8$ and/or K5.

\section{Keywords}

histone post-translational modification; mass spectrometry; Lys-D4; isotope-labeled mass tag

\footnotetext{
*To whom correspondence should be addressed. feitas.5@osu.edu.

$\dagger$ Mass Spectrometry and Proteomics Facility, Campus Chemical Instrument Center, The Ohio State University.

\#Department of Chemistry, The Ohio State University.

$\S$ Division of Hematology/Oncology, The Ohio State University.

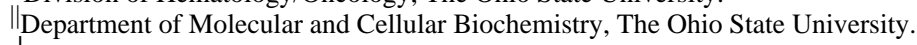

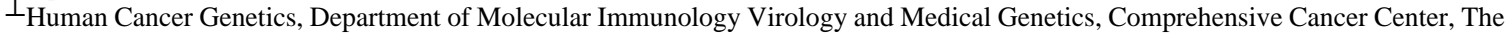
Ohio State University.

Supporting Information Available: Tables listing the mass and no. of lysine residues of observed peptides and the MS/MS assignment and identification of peak $466.44^{3+}$; figures showing the optimization of the incorporation of Lys-D4 into histone H4 and the plot of unique tryptic peptides vs mass accuracy with and without the constraint of no. of lysine residues. This material is available free of charge via the Internet at http://pubs.acs.org.
} 


\section{Introduction}

Histones are a group of conserved, highly basic proteins involved in the assembly of chromatin. The core histones form an octamer comprised of two H2A-H2B dimers and an H3-H4 tetramer. The octamer is complexed with $\sim 150$ base pairs of the DNA that wrap around the complex $\sim 1.8$ times to form a nucleosome. ${ }^{1,2}$ The core histones are subjected to many posttranslational modifications such as acetylation (lysine), methylation (lysine and arginine), phosphorylation (tyrosine, serine, and threonine), and ubiquitination (lysine). These modifications play important roles in gene transcriptional regulation ${ }^{3-6}$ and constitute the basis for the histone code hypothesis. ${ }^{7,8}$ Among all the post-translational modifications, the acetylation of histones has been extensively studied because it directly participates in the regulation of transcription via histone-DNA interactions. ${ }^{3}$

The acetylation of histones is dependent on two families of enzymes: histone acetyl transferases (HATs) $)^{9}, 10$ and histone deacetylases (HDACs). ${ }^{11-13}$ By adding acetyl groups to histone lysine residues, HATs promote gene transcription, whereas by removing acetyl groups, HDACs lead to transcriptionally silent chromatin. The abnormal activity of these enzymes is believed to play a major role in silencing tumor suppressor genes, thereby promoting malignant transformation in many types of cancers including acute myeloid leukemia (AML). ${ }^{14-19}$ These transforming mechanisms are particularly relevant for a common cytogenetic subgroup of AML harboring $\mathrm{t}(8 ; 21)$ that, at the molecular level, results in a fusion gene encoding a dominant transcriptional repressor, AML1/ETO. The latter is responsible for recruiting a transcription repression complex inclusive of class I histone deacetylases (i.e., HDAC1, -2 , and -3), which induce aberrant chromatin deacetylation, thereby repressing genes important for normal hematopoiesis. ${ }^{20,21}$ Therefore, molecular therapies that inhibit HDAC activities may be useful to remove gene repression and restore normal patterns of hematopoietic differentiation in this particular subtype of AML. ${ }^{17,18}$ In recent years, an increasing number of structurally diverse HDAC inhibitors have been identified with the potential to inhibit the proliferation and/or induce apoptosis in tumor cells in vitro and in vivo. ${ }^{22-25}$ Depsipeptide (FK-228) is one such agent that has been extensively studied for its anti-tumor properties due to its high selectivity. 24

Several methods have been used to investigate sequential acetylation at the $\mathrm{H} 4 \mathrm{~N}$-terminal lysine residues. For example, microsequencing techniques have been exploited for the study of histone acetylation patterns. ${ }^{26-29}$ This method consumes large quantity of pure sample (5$10 \mu \mathrm{g}$ of pure peptide), requiring multiple chromatographic purifications. Alternatively, Turner et al. investigated the acetylation pattern of $\mathrm{H} 4$ from different species by the use of acid urea gels, Western blotting, and immunolabeling with site-specific antibodies. ${ }^{30-34}$ This method is very sensitive but relies on the specificity and availability of antibodies, which have come under scrutiny. ${ }^{35,36}$

Peptide mapping by mass spectrometry has also been extensively used as a powerful approach for the identification of proteins and investigation of post-translational modifications. ${ }^{37-39}$ For example, Person et al. used peptide mass mapping to determine $\mathrm{H} 4$ acetylation from different $\mathrm{H} 4$ isoforms separated by acetic acid-urea polyacrylamide gel electrophoresis (AU-PAGE) and in-gel-digested with chymotrypsin. ${ }^{40}$ While peptide mass mapping is extensively used for protein identification of relatively pure proteins, ${ }^{39,41,42}$ it is not well-suited for the analysis of protein mixtures. For histone characterization, the presence of multiple isoforms can significantly complicate the mass spectra. Furthermore, peptide mass mapping cannot distinguish between peptides that have the same nominal mass. ${ }^{38,39,43}$ For example, in the tetracetylation isoform of $\mathrm{H} 4$, fragment 4-17 (GKGGKGLGKGGAKR) has the same nominal mass as that of the unmodified fragment 79-91 (KTVTAMDVVYALK). These two peptides differ in mass by $10 \mathrm{ppm}$ (1438.8130 vs $1438.7980 \mathrm{Th})$ and would require a mass resolving 
power of 95921 in order to observe two distinct peaks for each species. Thus, tandem mass spectrometry (MS/MS) is necessary to provide additional structural information. However, tandem MS typically requires greater starting material than MALDI-TOF MS ( $1 \mu \mathrm{g}$ for nanoLC-MS/MS vs 50 ng for MALDI-TOF MS). Furthermore, low-abundance species are likely not to be selected for MS/MS in favor of more abundant ions.

One way to improve the confidence of peptide identification in the absence of MS/MS data is by encoding sequence-dependent information into the peptide's mass. One such approach exploits metabolic labeling to incorporate a heavy isotope into the proteins produced in a proliferating cell line. ${ }^{41,44-46}$ Such an approach is used in the field of quantitative proteomics. $37,45,47,48$ Labeling is accomplished by growing the cells in a media enriched with an isotopically heavy amino acid. The labeled and unlabeled proteins can be mixed, digested, and mass-analyzed. Peptides that contain a heavy isotope-labeled amino acid will possess an isotopic signature that can be used to obtain a more confident peptide assignment. Pan et al. have demonstrated this approach (Amino Acid Coded Mass tagging, AACM) with peptides containing leucine, lysine, methionine, serine, arginine, and tyrosine ${ }^{49}$ In their work, AACM was proved to be efficient in identifying the highly hydrophobic and/or low-abundance proteins in a complicated protein mixture by MALDI-TOF MS. We have adopted the same approach to encode sequence information in the mass spectra of histones. For this work, lysine- $\mathrm{D}_{4}$ was chosen to introduce an amino acid mass tag. Peptides containing either labeled or unlabeled lysine residues will have characteristic light/heavy isotopic distribution patterns. The number of lysine residues in this fragment can be determined directly from the mass difference between the labeled and unlabeled peptides. This approach is especially valuable in the investigation of histone post-translational modifications because of the presence of isobaric peptide interferences. For example, the previously mentioned interference between fragments 4-17 and 79-91 would be distinguishable. The former peptide contains four lysines and would have a peptide pair separated by $16 \mathrm{Da}$. The latter peptide only has two lysines, resulting in a mass difference of $8 \mathrm{Da}$. The partial amino acid composition obtained directly from the isotope distribution simplifies data interpretation and allows quick identification of peptides and their post-translational modifications. The method is especially powerful when the abundance of the peptides may not allow MS/MS identification.

In this paper, we describe an approach for the confident assignment of histone lysine acetylation. AML1/ETO-positive Kasumi-1 cells were grown in regular media and media where lysine was replaced with deuterated lysine $\left(\right.$ Lys- $\left.\mathrm{D}_{4}\right)$. Depsipeptide (a Histone Deactylase Inhibitor) was also added to both media, and an equivalent number of cells were pooled at different exposure times $(0,4,8,12,24$, and $48 \mathrm{~h})$. The cells were mixed and histones extracted. $\mathrm{H} 4$ acetylation isoforms were separated using AU-PAGE followed by in-gel digestion with trypsin. The digests were analyzed by MALDI-TOF MS. The peptides were identified based on their mass and the number of lysine residues they contained.

\section{Experimental Procedures}

\section{Cell Line Preparation}

Kasumi-1 cells were cultured in RPMI 1640 (Modified 51501, with L-glutamine, without lysine, JRH Bioscience, Lenexa, KS) supplemented with $15 \%$ of dialyzed fetal bovine serum (Invitrogen, Carlsbad, CA). Cells were labeled by culturing them in L-lysine- $\mathrm{D}_{4} \cdot 2 \mathrm{HCl}$ (Cambridge Isotope Laboratories, MA). After complete labeling, Kasumi-1 cells were seeded at a density of $5 \times 10^{5} / \mathrm{mL}$ and exposed to depsipeptide as previously reported. ${ }^{50}$ 


\section{Acetic Acid-Urea Polyacryamide Gel Electrophoresis (AU-PAGE)}

Histones were extracted by use of a previously described acid extraction procedure. $39,51,52$ Histone acetylation isoforms were separated by AU-PAGE consisting of $6 \mathrm{M}$ urea, $15 \%$ acrylamide (acrylamide/bis-acrylamide 37.5:1), and 10\% acetic acid (all purchased from Sigma, St. Louis, MO). ${ }^{53-55}$ Briefly, the gel was conditioned at $300 \mathrm{~V}$ (constant voltage) overnight using $5 \%$ acetic acid as the running buffer. Core histones dissolved in $15 \mu \mathrm{L}$ of loading buffer ( $2 \mathrm{M}$ urea, $2 \% \beta$-mercaptoethanol, and 5\% acetic acid, Sigma, St. Louis, MO) were then loaded onto the gel, and the gel was run at $200 \mathrm{~V}$ for $2 \mathrm{~h}$ before the voltage was switched to $300 \mathrm{~V}$ for $20 \mathrm{~h}$ at $4{ }^{\circ} \mathrm{C}$. After electrophoresis, the gel was fixed in a 50:40:10 solution of ethanol (VWR Scientific, Bridgeport, NJ), water, and acetic acid for $4 \mathrm{~h}$ and then washed twice for $30 \mathrm{~min}$ in a 50:45:5 solution of methanol (VWR Scientific, Bridgeport, NJ), water, and acetic acid. The gel was then stained using Coomassie Brilliant Blue for $30 \mathrm{~min}$ and destained in 65:30:5 water, methanol, and acetic acid until protein bands were observed with minimal background.

\section{In-Gel Digestion}

Gels were digested with modified sequencing grade trypsin (Promega, Madison, WI) using the Montage In-Gel Digestion Kit (Millipore, Bedford, MA). The gel bands were trimmed to minimize background polyacrylamide before they were washed twice in 50\% methanol/5\% acetic acid ( $1 \mathrm{~h}$ each). The gel slices were then twice dehydrated with acetonitrile and rehydrated with $100 \mathrm{mM}$ ammonium bicarbonate. Trypsin (400-600 ng) in $50 \mathrm{mM}$ ammonium bicarbonate was added to each gel band. After the mixture was incubated on ice for $10 \mathrm{~min}$, an additional $20 \mu \mathrm{L}$ of $50 \mathrm{mM}$ ammonium bicarbonate was added. The mixture was then incubated for $2 \mathrm{~h}$ at $37^{\circ} \mathrm{C}$ before the peptides were extracted by repeated washing with $50 \%$ acetonitrile $/ 5 \%$ formic acid. The extracted pools were concentrated under vacuum to a final volume of $\sim 20 \mu \mathrm{L}$.

\section{Solution-Phase Arg-C Digestion}

The extracted core histones were digested with Arginine-C endopeptidase (Clostripain Princeton, Adelphia, NJ). The core histones were dissolved in the reaction buffer $(50 \mathrm{mM}$ Tris $\mathrm{HCl}, 7.5 \mathrm{mM}$ dithiothreitol, and $1 \mathrm{mM}$ calcium acetate at final $\mathrm{pH}=8.0$ ). The enzyme was resuspended in the same buffer and incubated with the protein at a ratio of 1:100 (enzyme/ substrate) overnight at room temperature. The reaction was quenched with $0.1 \%$ trifluoroacetic acid (TFA), and the peptides were desalted prior to the LC-MS/MS analysis.

\section{Liquid Chromatography Mass Spectrometry}

Core histones were separated by use of reversed-phase high-performance liquid chromatography (Waters 2690, Waters, Milford, MA). Water with $0.1 \%$ TFA and acetonitrile (ACN) with $0.1 \%$ TFA were used as mobile phases A and B. A $20 \mu \mathrm{L}$ aliquot of core histones $(50-100 \mu \mathrm{M}$ ) was injected and separated on a C18 column (Supelco LC-C18-DB $4.6 \times 250$ $\mathrm{mm}$, Supelco, Inc., Bellefonte, PA). The reversed-phase gradient was $25 \%-48 \%$ from 0 to 2 min, $48 \%-60 \%$ from 2 to $16 \mathrm{~min}$, and maintained at $60 \% \mathrm{~B}$ until $22 \mathrm{~min}$. The column was washed with $100 \% \mathrm{~B}$ for $1 \mathrm{~min}$ and equilibrated with $25 \% \mathrm{~B}$ for $4 \mathrm{~min}$ prior to the next injection. The flow rate was $1 \mathrm{~mL} \mathrm{~min}{ }^{-1}$. Histones eluting from the column were detected with a UV detector $(\lambda=214 \mathrm{~nm})$. A Micromass LCT (Micromass, Wythenshawe, U.K.) mass spectrometer with an orthogonal electrospray source (Z-spray) was coupled to the outlet of the HPLC using a T-splitter. Histones were infused into the electrospray source at the flow rate of about 20 $\mu \mathrm{L} / \mathrm{min}$ (split ratio $=50: 1$ ). For the optimal ESI conditions, capillary voltage was $3 \mathrm{kV}$, source temperature was $100^{\circ} \mathrm{C}$, and cone voltage was $50 \mathrm{~V}$. NaI was used for external mass calibration over the $\mathrm{m} / \mathrm{z}$ range of 500-2500. Data were acquired in continuum mode at the rate of 1 
spectrum $\mathrm{s}^{-1}$. Zero charge mass spectra were generated using the MaxEnt routinely available within the MassLynx data analysis software. All spectra were obtained in the positive ion mode.

\section{Matrix-Assisted Laser Desorption/lonization Time-of-Flight Mass Spectrometry (MALDI-TOF MS)}

MALDI-TOF MS was performed on a Reflex III (Bruker Daltonics, Inc., Billerica, MA) mass spectrometer operated in reflection, positive ion mode at an accelerating voltage of $28 \mathrm{kV}$. The $\mathrm{N}_{2}$ laser was operated at minimum threshold level required to generate signal and minimize dissociation. The instrument was calibrated with peptide standards. The matrix, $\alpha$-cyano-4hydroxy cinnamic acid (HCCA), was prepared as a saturated solution in $50 \% \mathrm{ACN}$ with $0.1 \%$ TFA in water. Aliquots consisting of $5 \mu \mathrm{L}$ of matrix and $1 \mu \mathrm{L}$ of sample were thoroughly mixed, spotted on the target plate $(1.0 \mu \mathrm{L})$, and allowed to dry before analysis.

\section{Capillary-Liquid Chromatography-Nanospray Tandem Mass Spectrometry (Nano-LC-MS/ MS)}

Nano-LC-MS/MS was performed on a hybrid quadrupole time-of-flight mass spectrometer (Q-TOF II, Micromass, Wythenshawe, U.K.) equipped with an orthogonal nanospray source (New Objective, Inc., Woburn, MA) operated in positive ion mode. The LC system was a Dionex UltiMate (TM) system (Dionex, Sunnyvale, CA). Solvent A was $50 \mathrm{mM}$ acetic acid, and solvent B was acetonitrile. The peptides ( $2.5 \mu \mathrm{L}$ injection) were separated on a $5 \mathrm{~cm}, 75$ $\mu \mathrm{m}$ i.d. ProteoPep C18 column (New Objective, Inc., Woburn, MA) packed within the nanospray tip. Peptides were eluted directly from the column into the MS. The gradient was $2-80 \% \mathrm{~B}$ from 0 to $30 \mathrm{~min}$ at a flow rate of $300 \mathrm{~nL} / \mathrm{min}$ (precolumn split from $40 \mu \mathrm{L} / \mathrm{min}$ ). The total run time was $55 \mathrm{~min}$. The nanospray capillary voltage was set at $3.0 \mathrm{kV}$ and the cone voltage at $55 \mathrm{~V}$. The source temperature was maintained at $100^{\circ} \mathrm{C}$. Data-dependent tandem mass spectra were obtained using the MassLynx 4.0 automatic MS switching functions. Mass spectra were acquired for the $\mathrm{m} / \mathrm{z}$ range of 400-2000 Th every second at a resolution of 8000 (fwhm). Tandem MS of selected peptides was accomplished by use of included tables. Sequence information from the MS/MS data was obtained using Mascot (Matrix Science, Boston, MA).

\section{Results and Discussion}

\section{Amino Acid Coded Mass Tagging of Depsipeptide-Treated Kasumi-1 Cells}

The prevailing goal of this work was the evaluation of AACM MALDI-TOF MS to elucidate histone acetylation patterns with high confidence from transformed cells treated with a HDAC inhibitor. The AML1/ETO-positive Kasumi-1 cell line has been extensively investigated as an example of HDAC-dependent leukemogenesis. ${ }^{56-58}$ In 2003, the Marcucci group published a paper that showed depsipeptide promoted histone acetylation, gene transcription, and apoptosis in AML1/ETO-positive leukemic cells. ${ }^{50}$ Furthermore, its activity was enhanced by DNA methyltransferase inhibitors leading to additional study of synergistic effects of combined therapies. The pharmacological activity of depsipeptide on $\mathrm{t}(8 ; 21)$ Kasumi-1 cells was described in their study. Depsipeptide conferred a dose-dependent increase in $\mathrm{H} 3$ and H4 acetylation measured by immunoblotting. Consistent with this biological effect, a dosedependent gene re-expression, partial cell differentiation, and increase in apoptosis were observed. Therefore, this cell line constitutes a relevant model to study pharmacologically induced histone modifications.

To investigate the incorporation of the stable isotope, cells were grown separately in Lys- $\mathrm{D}_{0}$ and Lys- $\mathrm{D}_{4}$ media for $1-4$ cell cycles. Histones were then extracted and subjected to LC-MS to determine the mass shift due to the stable isotope labeling. Since histone $\mathrm{H} 4$ contains 11 lysine residues, Lys- $\mathrm{D}_{4}$-labeled $\mathrm{H} 4$ should carry a mass shift of $44 \mathrm{Da}$ (11 $\left.350 \mathrm{Da}\right)$ compared 
to unlabeled H4 (11 $306 \mathrm{Da})$. The LC-MS data showed that, after three cell cycles, the incorporation of Lys- $\mathrm{D}_{4}$ into $\mathrm{H} 4$ was complete (Figure 1 in the Supporting Information). To ensure complete incorporation, cells were grown in the Lys- $\mathrm{D}_{4}$ media for a minimum of 4 cell cycles before any treatment.

Labeled and unlabeled Kasumi- 1 cells were then exposed to $3.0 \mathrm{nM}$ depsipeptide for 0-48 h. Cell viability was approximately $80 \%$ at $48 \mathrm{~h}$ following drug exposure. The labeled and unlabeled cells were then mixed in equivalent numbers. Histones were acid-extracted from the mixture and separated by AU-PAGE. Three isoforms of $\mathrm{H} 4$ were observed at incubation times of 0 and $4 \mathrm{~h}$ corresponding to 0,1 , and 2 lysine acetylations of H4 (Figure 1). NOTE: The labeling of the N-terminally acetylated isoform of $\mathrm{H} 4$ is referred to as the 0 or no acetylation in order to be consistent with other references. ${ }^{59,60}$ The triacetylated isoform appeared at 8and 12-h treatment, and the tetra-acetylated isoform was present at 24 and $48 \mathrm{~h}$. Each gel band representing a different $\mathrm{H} 4$ isoform was then excised, in-gel-digested with trypsin, and massanalyzed by MALDI-TOF MS. The sequence coverage for all the isoforms was $67-75 \%$.

AACM MALDI-TOF MS was then used to differentiate between isobaric peptides. The Lys$\mathrm{D}_{4}$ label introduced a mass shift of $4 \times N(N=$ the number of lysine residues) for the tryptic peptides. Thus, the mixture of labeled and unlabeled peptides gave an isotopic pattern in which the number of lysine residues in the peptide was easily determined (Figure 2). In addition, since histone acetylation only occurs on lysine residues, only those peaks with the characteristic isotopic pattern were targeted for further analysis. For example, the fragment 46-55 (ISGLIYEETR) at $1180.68^{+}$Th has no heavy isotopic partner and can be concluded to contain no lysine residues. In contrast, the light/heavy peptide pattern at $1325.78: 1329.79^{+} \mathrm{Th}$ corresponds to a peptide with one lysine and can be assigned to a single peptide of unique mass and lysine content, fragment 24-36 (DNIQGITKPAIR). Likewise, the light/heavy peptide pattern at 1396.85:1412.84 ${ }^{+}$Th corresponds uniquely to fragment 4-17

(GKGGKGLG $\underline{K G G A} \underline{K} R+3$ acetylations). More importantly, the use of two constraints (mass and no. of lysines) can increase the confidence in peptide identification, especially for those isobaric peptides with different lysine content. For example, the fragment at $885.55^{+} \mathrm{Th}$ observed in the monoacetylation band could be identified as either the monoacetylatyl isoform of fragment 9-17 (GLGKGGAKR, 885.5270 ${ }^{+} \mathrm{Th}$ ) or the diacetylatyl isoform of fragment 412 (GKGGKGLGK, 885.5158+ Th). However, since a light/heavy peptide pair was observed at $885.55: 893.57^{+} \mathrm{Th}(\Delta M=8 \mathrm{Da})$, the peptide must contain two lysine residues. Therefore, the peptide was assigned uniquely as fragment 9-17. Similarly, the peak at $672.40^{+}$Th was identified as 40-45 (RGGVKR, 672.4269+ Th) instead of the monoacetyl, monomethyl isoform of fragment 6-12 (GGKGLGK $672.4044^{+}$Th) due to the presence of heavy isotopic partner at $676.43^{+} \mathrm{Th}$. Similarly, the fragment at $1466.95^{+}$Th with a heavy isotopic partner at $1470.96^{+}$Th was assigned as fragment 80-92 (TVTAMDVVYALKR, $1466.8041^{+}$Th) rather than fragment 79-91 (ㅈTVTAMDVVYALㅌR, 1466.8293+ Th), and the fragment at $1577.92^{+}$Th with heavy isotopic partner at $1581.92^{+}$Th was assigned as fragment $46-59$ (ISGLIYEETRGVLK, $1577.8903^{+} \mathrm{Th}$ ) as opposed to the monomethylated isoform of

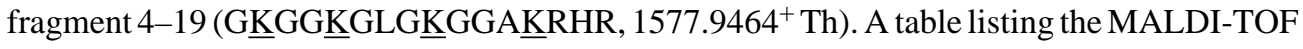
MS masses for all samples and the proposed assignments based on mass and number of lysine residues is provided in the Supporting Information. Despite the power of the method, it is important to note that AACM with $\mathrm{D}_{4}$ lysine cannot distinguish between isobaric PTMs such as trimethylation and acetylation.

\section{Histone Modifications}

The MALDI mass spectra for each isoform were compared over the course of treatment with DDP. Several light/heavy peptide pairs were present within particular isoforms regardless of 
exposure time to DDP. This observation suggests that some modification states are pervasive in Kasumi-1 cells. These peptides and their modifications are discussed below.

The first $\mathrm{H} 4$ band corresponding to the 0 acetylation band contained only one modified peptide as identified by AACM MALDI-TOF MS. A peak at $543.51^{+}$Th was observed, representing the dimethylation of fragment 20-23 (KVLR). K20 is known to be predominantly dimethylated in mammalian cells. ${ }^{61,62}$ Thus, it was assumed to be the site of dimethylation (Figure 3A).

Other unmodified fragments were also identified by this approach. A light/heavy peptide pair was observed at 488.35:492.31 $1^{+}$Th that matched the unmodified form of fragment 13-17 (GGAKR), suggesting unmodified K16 in the 0 -acetylation isoform (Figure 3A). Peptides corresponding to other $\mathrm{N}$-terminal lysine-containing peptides were not observed. This lack of sequence coverage is due to complete tryptic digestion of the $\mathrm{H} 4 \mathrm{~N}$-terminus, which generates small hydrophilic peptide fragments presenting a low $m / z(<500)$ that are often not observed in MALDI-TOF MS due to chemical interference from the matrix and not observed in LCMS since those are not retained on reversed-phase C18 columns.

In the next higher acetylation isoform, dimethylation of K20 was also observed. The light/ heavy pair at 488.31:492.31 ${ }^{+}$Th corresponding to the unmodified fragment 13-17 (GGAKR) disappeared, while a new light/heavy pair at 530.40:534.42+ Th was observed (Figure 3B). The mass difference between $488.31^{+}$and $530.42^{+}$Th corresponded to the mass of acetylation (42.01 Da). Thus, the light/heavy pair was concluded to be due to monoacetylation of K16 in fragment 13-17 (GGAKR). Occasionally, a light/heavy peptide pair with low abundance was observed at 885.55:893.57 $7^{+}$Th (Supplementary Table 1 in Supporting Information, 0 and 24 $\mathrm{h}$ treatment). On the basis of the isotopic distribution pattern and the mass shift ( $8 \mathrm{Da})$, this peak was identified as the monoacetylation of fragment 9-17 (GLGKGGAKR), suggesting that either K16 or K12 could be acetylated. However, other studies have shown K16 as the primary acetylation site in humans and other mammals. ${ }^{29,34}$ On the basis of this information and the fact that the peak was only occasionally observed at low abundance, this peptide may also be due to incomplete tryptic digestion.

The tryptic digestion from the $\mathrm{H} 4$ diacetylation band showed that, in addition to the dimethylation of K20, acetylation was concomitantly observed on K16 and K12 (Figure 3C). A fragment was observed at $927.70^{+} \mathrm{Th}$, which can be assigned as either the diacetylated isoform of fragment 9-17 (GLGKGGAKR, 927.5376 $\mathrm{Th}$ ) or the triacetylated isoform of

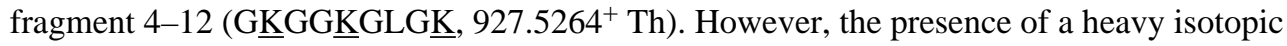
partner observed at $935.72^{+}$Th indicated that this peptide contains only two lysine residues as opposed to three. In addition, acetylation breaks the electrostatic interactions between lysine (from histone) and Asp-189 on the trypsin catalytic pocket, causing a resistance to trypsin digestion. ${ }^{63}$ Thus, acetylated lysine must be an internal residue within a tryptic fragment. This fragment was then assigned as the diacetylated isoform of fragment 9-17 with the acetylation sites at K12 and K16. However, studies also showed that, in human and mammals, acetylation following K16 can occur at K12, K5, and K8. ${ }^{27,29,34}$ These observations were partially corroborated in the present study. A mass shift of 42 Da was observed for fragment 13-17 (GGAKR), suggesting trypsin cleavage at K12. Since trypsin cannot recognize and cleave an acetylated lysine residue, K12 must be partially unmodified in this band and an additional site of acetylation located elsewhere.

Results from the tryptic digestion of the triacetylated band showed that K16, K12, and K8/K5 were acetylated in addition to the dimethylation of K20. As shown in Figure 4A, a light/heavy pair at 1397.02:1413.05 $\mathrm{Th}(\Delta M=16 \mathrm{Da}, 4 \mathrm{~K}$ 's $)$ was observed and assigned as the triacetylated isoform of fragment 4-17 (GKGGKGLGKGGAKR). The patterns of acetylations could be assigned as the following combinations: K16/K12/K8, K16/K12/K5, K5/K8/K12, or K5/K8/ K16. A peak at $1211.82: 1223.85^{+} \mathrm{Th}(\Delta M=12 \mathrm{Da}, 3 \mathrm{~K}$ 's $)$ was observed and identified as the 
triacetylated isoform of fragment 6-17 (GGKGLGGGGAKR), supporting acetylations of K16, $\mathrm{K} 12$, and $\mathrm{K} 8$. In addition, some other observations supported that $\mathrm{K} 5$ could be acetylated in addition to $\mathrm{K} 12$ and $\mathrm{K} 16$. A peak observed at $927.70^{+} \mathrm{Th}$ with a mass shift of $8 \mathrm{Da}$ was assigned as the diacetylation of fragment 9-17 (GLGKGGAKR), suggesting trypsin cleavage occurred $\mathrm{C}$-terminally to K8. Therefore, K8 would be unmodified, and the third acetylation likely was located on K5. No species were observed supporting acetylation on K5/K8/K12 or K5/K8/ K16.

To verify the assignment from MALDI-TOF MS, tandem mass spectrometry was performed

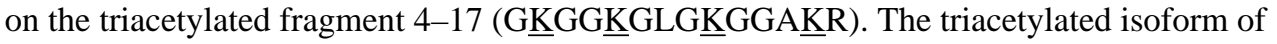
fragment 4-17 possessed two distinct patterns of acetylation depending upon the charge state of the precursor ion (Figure 5). The triply charged precursor $\left(466.44^{3+} \mathrm{Th}\right)$ produced a series of ions that corresponded to acetylation of K16, K12, and K5 (Figure 5A). The doubly charged precursor $\left(699.16^{2+} \mathrm{Th}\right.$, Figure $\left.5 \mathrm{~B}\right)$ yielded a fragmentation pattern that matched the acetylation of K16, K12, and K8 on fragment 4-17 (see supplemental Table 2 in Supporting Information for detailed assignments).

Tryptic digestion of the tetracetylation band showed that K16, K12, K8, and $\mathrm{K} 5$ were all acetylated in addition to the dimethylation on K20 (Figure 4B). A light/heavy pair at 1439.01: $1455.13^{+} \mathrm{Th},(\Delta M=16 \mathrm{Da}, 4 \mathrm{~K}$ 's) was assigned as the tetra-acetylated isoform of fragment 4-17 (GKGGKGLGKGGAKRR). Thus, the acetylations were assigned to K16, K12, K8, and $\mathrm{K} 5$. AACM was necessary to distinguish between multiple assignments for the peptide pair at 1850.2:1858. $3^{+} \mathrm{Th}$, observed in all isoforms (Table 1). Three isobaric peptides with a nominal mass of $1850^{+}$Th are possible: (1) fragment 21-36 (VLRD-NIQGITKPAIRR, 1850.1088 ${ }^{+}$ Th), (2) dimethylated fragment 24-39 (DNIQGITKPAIRRLAR, $1850.1088^{+} \mathrm{Th}$ ), and (3) dimethylated fragment 20-35 (KVLRDNIQGITKPAIR, 1850.1340+ Th). A mass accuracy of $13.6 \mathrm{ppm}$ would be required to distinguish among these as to the correct assignment. However, since the light/heavy pair was separated by $8 \mathrm{Da}$, this fragment contained two lysine residues and was thus assigned as the dimethylated isoform of fragment 20-35.

\section{Histone H4 Acetylation Patterns}

The histone $\mathrm{H} 4$ acetylation patterns have been investigated in several organisms. ${ }^{27-34}$ For example, the acetylation on cuttlefish initially occurs on K12, followed by K5, K16, and K8. ${ }^{27}$ A similar acetylation pattern was observed in Drosophila. ${ }^{28}$ However, studies showed different acetylation patterns in human and other mammals. Acetylation patterns obtained from pig thymus, ${ }^{29}$ bovine thymus, ${ }^{27}$ human HeLa S3 cells, ${ }^{29}$ and human promyeloid HL60 cells ${ }^{34}$ all showed initial acetylation of K16. The second acetylation occurred primarily on K12 with some at $\mathrm{K} 8$ or $\mathrm{K} 5$. $\mathrm{K} 8$ and $\mathrm{K} 5$ can be further acetylated until all four lysine residues were completely acetylated. As shown in Table 1, we observed K16 as the only residue acetylated in the monoacetylation band. In the di-acetylation band, K12 was observed as an acetylation site, as well as K16; however, the cleavage on K12 by trypsin in the same digests suggested that some of $\mathrm{K} 8$ or $\mathrm{K} 5$ may be partially acetylated. In the triacetylation band, acetylation on either K5 or K8 was observed in addition to K16 and K12. The tetracetylation band showed acetylation of $\mathrm{K} 5, \mathrm{~K} 8, \mathrm{~K} 12$, and $\mathrm{K} 16$.

\section{The Advantages of the Current Method: AACM-Based Mass Spectrometry}

It has been stated that the metabolic incorporation of deuterium-labeled lysine into histones increases the confidence in peptide identification. To assess the degree to which the assignment can be improved, we determined the number of unique peptides that could be assigned from an in silico digest both with and without the use of no. of lysines as a constraint. The in silico digest of human histone $\mathrm{H} 4$ included the following modifications: acetylation of lysine; mono-, di-, and trimethylation of lysine; mono and dimethylation of arginine; and 
phosphorylation of serine, tyrosine, and threonine. Five missed cleavages were allowed, and peptides that contained impossible modification patterns (such as acetylation of C-terminal lysine, peptides that contain a greater number of modifications than possible within the sequence, etc.) were eliminated. The final list contained 2499 peptides in the mass range of 500-3000 Da. In our study, AU-PAGE was employed to separate histone H4 into different bands. The in-gel-digested bands could not contain peptides that exceeded the number of acetylations of its corresponding gel band. Thus, AU-PAGE also placed an additional constraint on peptide assignments. Since this constraint is not general to AACM, it was not considered in this analysis but incorporated in the final citation of peptide matches.

Of all 2499 peptides, 1854 (74.19\%) had a unique mass and could be distinguished by a mass spectrometer with $<10 \mathrm{ppm}$ mass accuracy. When the no. of lysines is factored into the identification, the number of uniquely distinguishable peptides increases to $1869(74.79 \%)$. Furthermore, as the mass accuracy decreased beyond $10 \mathrm{ppm}$, a greater number of peptides could be distinguished when two constraints (mass and no. of lysines) were used as opposed to mass alone. For example, at 25 ppm, 1617 (64.71\%) peptides could be considered unique by mass measurement alone as compared to $1795(71.83 \%)$ with mass and no. of lysines. A plot of the no. of unique peptides identifiable by the two approaches as a function of mass accuracy is shown in Figure 2 of Supporting Information. From the plot, it is evident that the use of stable isotope-labeled amino acids consistently resulted in improved confidence in peptide assignment by $0.60 \%$ ( 15 peptides) at $10 \mathrm{ppm}$ to $7.12 \%$ (177 peptides) at $25 \mathrm{ppm}$ among the total 2499 peptides. Thus, while the improvement is small, it does support the argument of Pan et al. that AACM MALDI-TOF MS is useful for peptide assignment, especially in the cases where peptide abundances are too low to perform MS/MS. ${ }^{49}$

\section{Conclusion}

An integrated approach combining AU-PAGE, AACM, and MALDI-TOF MS was applied to investigate the acetylation patterns of $\mathrm{H} 4$. The results showed that $\mathrm{H} 4$ was primarily acetylated on K16, since only the acetylation of K16 was observed in the monoacetylated isoform. The secondary acetylation site was primarily on K12, although evidence suggested that K12 was not fully acetylated in the diacetylated isoform. Following the acetylation on K16 and K12, either $\mathrm{K} 5$ or $\mathrm{K} 8$ was acetylated in the triacetylated isoform. All four lysine residues were acetylated in the tetracetylated isoform.

Compared with traditional methods such as microsequencing and immunoassay, the mass spectrometric approach has the advantage of high accuracy, high sensitivity, and rapid analysis. More importantly, lysine was used as the heavy isotope-labeled amino acid encoded mass tag, which greatly simplifies the data analysis because acetylations occur only on lysine residues. In addition, partial amino acid composition information obtained directly from the isotope distribution pattern can be used to improve the confidence of peptide identification without further MS/MS identification.

\section{Acknowledgments}

The authors thank Chen Ren for help with the AU-PAGE. We also thank Dr. Kari Green-Church, Ms. Rhonda Pitsch, and Nanette Kleinholz at Campus Chemical Instrumentation Center for assistance with MALDI-TOF MS and nanoLC-MS/MS experiments. The study was funded by the Ohio State University, the Camille and Henry Dreyfus Foundation, the American Society for Mass Spectrometry, and National Institutes of Health CA107106 (to M.A.F), National Institutes of Health GM62970 (to M.R.P.), and National Institutes of Health CA102031 (to G.M.). 


\section{References}

1. Luger K, Mader AW, Richmond RK, Sargent DF, Richmond TJ. Crystal structure of the nucleosome core particle at $2.8 \AA$ resolution. Nature 1997;389(6648):251-60. [PubMed: 9305837]

2. Luger K, Richmond TJ. The histone tails of the nucleosome. Curr Opin Genet Dev 1998;8(2):140-6. [PubMed: 9610403]

3. Annunziato AT, Hansen JC. Role of histone acetylation in the assembly and modulation of chromatin structures. Gene Expression 2000;9(1-2):37-61. [PubMed: 11097424]

4. Berger SL. Histone modifications in transcriptional regulation. Curr Opin Genet Dev 2002;12(2):1428. [PubMed: 11893486]

5. Kouzarides T. Histone methylation in transcriptional control. Curr Opin Genet Dev 2002;12(2):198209. [PubMed: 11893494]

6. Ng HH, Feng Q, Wang H, Erdjument-Bromage H, Tempst P, Zhang Y, Struhl K. Lysine methylation within the globular domain of histone $\mathrm{H} 3$ by Dot 1 is important for telomeric silencing and Sir protein association. Genes Dev 2002;16(12):1518-27. [PubMed: 12080090]

7. Jenuwein T, Allis CD. Translating the histone code. Science 2001;293(5532):1074-80. [PubMed: 11498575]

8. Turner BM. Cellular memory and the histone code. Cell 2002;111(3):285-91. [PubMed: 12419240]

9. Hasan S, Hottiger MO. Histone acetyl transferases: a role in DNA repair and DNA replication. J Mol Med 2002;80(8):463-74. [PubMed: 12185447]

10. Lopez-Rodas G, Brosch G, Golderer G, Lindner H, Grobner P, Loidl P. Enzymes involved in the dynamic equilibrium of core histone acetylation of Physarum polycephalum. FEBS Lett 1992;296 (1):82-6. [PubMed: 1730297]

11. Cress WD, Seto E. Histone deacetylases, transcriptional control, and cancer. J Cell Physiol 2000;18 (1):1-16. [PubMed: 10825229]

12. de Ruijter AJ, van Gennip AH, Caron HN, Kemp S, van Kuilenburg AB. Histone deacetylases (HDACs): characterization of the classical HDAC family. Biochem J 2003;370(Pt 3):737-49. [PubMed: 12429021]

13. Lopez-Rodas G, Brosch G, Georgieva EI, Sendra R, Franco L, Loidl P. Histone deacetylase. A key enzyme for the binding of regulatory proteins to chromatin. FEBS Lett 1993;317(3):175-80. [PubMed: 8425601]

14. Archer SY, Hodin RA. Histone acetylation and cancer. Curr Opin Genet Dev 1999;9(2):171-4. [PubMed: 10322142]

15. Gray SG, Teh BT. Histone acetylation/deacetylation and cancer: an "open" and "shut" case? Curr Mol Med 2001;1(4):401-29. [PubMed: 11899086]

16. Kouraklis G, Theocharis S. Histone acetylation and cancer. Acta Oncol 2003;42(7):792. [PubMed: 14690169]

17. Mahlknecht U, Hoelzer D. Histone acetylation modifiers in the pathogenesis of malignant disease. Mol Med 2000;6(8):623-44. [PubMed: 11055583]

18. Marks P, Rifkind RA, Richon VM, Breslow R, Miller T, Kelly WK. Histone deacetylases and cancer: causes and therapies. Nat Rev Cancer 2001;1(3):194-202. [PubMed: 11902574]

19. Wang C, Fu M, Mani S, Wadler S, Senderowicz AM, Pestell RG. Histone acetylation and the cellcycle in cancer. Front Biosci 2001;6:D610-29. [PubMed: 11282573]

20. Wang J, Hoshino T, Redner RL, Kajigaya S, Liu JM. ETO, fusion partner in t( $8 ; 21)$ acute myeloid leukemia, represses transcription by interaction with the human N-CoR/mSin3/HDAC1 complex. Proc Natl Acad Sci USA 1998;95(18):10860-5. [PubMed: 9724795]

21. Wang J, Saunthararajah Y, Redner RL, Liu JM. Inhibitors of histone deacetylase relieve ETOmediated repression and induce differentiation of AML1-ETO leukemia cells. Cancer Res 1999;59 (12):2766-9. [PubMed: 10383127]

22. Arts J, de Schepper S, Van Emelen K. Histone deacetylase inhibitors: from chromatin remodeling to experimental cancer therapeutics. Curr Med Chem 2003;10(22):2343-50. [PubMed: 14529477]

23. Pelicci PG. A new class of anti-cancer drugs: HDAC-inhibitors. Suppl Tumori 2002;1(4):S66. [PubMed: 12415827] 
24. Sandor V, Bakke S, Robey RW, Kang MH, Blagosklonny MV, Bender J, Brooks R, Piekarz RL, Tucker E, Figg WD, Chan KK, Goldspiel B, Fojo AT, Balcerzak SP, Bates SE. Phase I trial of the histone deacetylase inhibitor, depsipeptide (FR901228, NSC 630176), in patients with refractory neoplasms. Clin Cancer Res 2002;8(3):718-28. [PubMed: 11895901]

25. Secrist JP, Zhou X, Richon VM. HDAC inhibitors for the treatment of cancer. Curr Opin Invest Drugs 2003;4(12):1422-7.

26. Chicoine LG, Schulman IG, Richman R, Cook RG, Allis CD. Nonrandom utilization of acetylation sites in histones isolated from Tetrahymena. Evidence for functionally distinct $\mathrm{H} 4$ acetylation sites. J Biol Chem 1986;261(3):1071-6. [PubMed: 3080415]

27. Couppez M, Martin-Ponthieu A, Sautiere P. Histone H4 from cuttlefish testis is sequentially acetylated. Comparison with acetylation of calf thymus histone H4. J Biol Chem 1987;262(6):285460. [PubMed: 3818624]

28. Sobel RE, Cook RG, Allis CD. Non-random acetylation of histone H4 by a cytoplasmic histone acetyltransferase as determined by novel methodology. J Biol Chem 1994;269(28):18576-82. [PubMed: 8034606]

29. Thorne AW, Kmiciek D, Mitchelson K, Sautiere P. Crane-Robinson, C., Patterns of histone acetylation. Eur J Biochem 1990;193(3):701-13. [PubMed: 2249688]

30. Munks RJ, Moore J, O’Neill LP, Turner BM. Histone H4 acetylation in Drosophila. Frequency of acetylation at different sites defined by immunolabelling with site-specific antibodies. FEBS Lett 1991;284(2):245-8. [PubMed: 2060643]

31. Sommerville J, Baird J, Turner BM. Histone $\mathrm{H} 4$ acetylation and transcription in amphibian chromatin. J Cell Biol 1993;120(2):277-90. [PubMed: 8421048]

32. Turner BM, Birley AJ, Lavender J. Histone H4 isoforms acetylated at specific lysine residues define individual chromosomes and chromatin domains in Drosophila polytene nuclei. Cell 1992;69(2): 375-84. [PubMed: 1568251]

33. Turner BM, Fellows G. Specific antibodies reveal ordered and cell-cycle-related use of histone-H4 acetylation sites in mammalian cells. Eur J Biochem 1989;179(1):131-9. [PubMed: 2917555]

34. Turner BM, O'Neill LP, Allan IM. Histone H4 acetylation in human cells. Frequency of acetylation at different sites defined by immunolabeling with site-specific antibodies. FEBS Lett 1989;253(12):141-5. [PubMed: 2474456]

35. Muller S, Isabey A, Couppez M, Plaue S, Sommermeyer G, Van Regenmortel MH. Specificity of antibodies raised against triacetylated histone H4. Mol Immunol 1987;24(7):779-89. [PubMed: 2443844]

36. Pfeffer U, Ferrari N, Vidali G. Availability of hyperacetylated $\mathrm{H} 4$ histone in intact nucleosomes to specific antibodies. J Biol Chem 1986;261(6):2496-8. [PubMed: 3949730]

37. Freitas MA, Sklenar AR, Parthun MR. Application of mass spectrometry to the identification and quantification of histone post-translational modifications. J Cell Biochem 2004;92(4):691-700. [PubMed: 15211567]

38. Zhang K, Tang H, Huang L, Blankenship JW, Jones PR, Xiang F, Yau PM, Burlingame AL. Identification of acetylation and methylation sites of histone $\mathrm{H} 3$ from chicken erythrocytes by highaccuracy matrix-assisted laser desorption ionization-time-of-flight, matrix-assisted laser desorption ionization-postsource decay, and nanoelectrospray ionization tandem mass spectrometry. Anal Biochem 2002;306(2):259-69. [PubMed: 12123664]

39. Zhang L, Eugeni EE, Parthun MR, Freitas MA. Identification of novel histone post-translational modifications by peptide mass fingerprinting. Chromosoma 2003;112(2):77-86. [PubMed: 12937907]

40. Person MD, Monks TJ, Lau SS. An integrated approach to identifying chemically induced posttranslational modifications using comparative MALDI-MS and targeted HPLC-ESI-MS/MS. Chem Res Toxicol 2003;16(5):598-608. [PubMed: 12755589]

41. Gu S, Pan S, Bradbury EM, Chen X. Use of deuterium-labeled lysine for efficient protein identification and peptide de novo sequencing. Anal Chem 2002;74(22):5774-85. [PubMed: 12463361]

42. Suckau D, Mak M, Przybylski M. Protein surface topology-probing by selective chemical modification and mass spectrometric peptide mapping. Proc Natl Acad Sci USA 1992;89(12):56304. [PubMed: 1608973] 
43. Zhang L, Freitas MA, Wickham J, Parthun MR, Klisovic MI, Marcucci G, Byrd JC. Differential expression of histone post-translational modifications in acute myeloid and chronic lymphocytic leukemia determined by high-pressure liquid chromatography and mass spectrometry. J Am Soc Mass Spectrom 2004;15(1):77-86. [PubMed: 14698558]

44. Everley PA, Krijgsveld J, Zetter BR, Gygi SP. Quantitative cancer proteomics: stable isotope labeling with amino acids in cell culture (SILAC) as a tool for prostate cancer research. Mol Cell Proteomics 2004;3(7):729-35. [PubMed: 15102926]

45. Ong SE, Foster LJ, Mann M. Mass spectrometric-based approaches in quantitative proteomics. Methods 2003;29(2):124-30. [PubMed: 12606218]

46. Ong SE, Kratchmarova I, Mann M. Properties of 13C-substituted arginine in stable isotope labeling by amino acids in cell culture (SILAC). J Proteome Res 2003;2(2):173-81. [PubMed: 12716131]

47. Gu S, Pan S, Bradbury EM, Chen X. Precise peptide sequencing and protein quantification in the human proteome through in vivo lysine-specific mass tagging. J Am Soc Mass Spectrom 2003;14 (1):1-7. [PubMed: 12504328]

48. Zhu H, Pan S, Gu S, Bradbury EM, Chen X. Amino acid residue specific stable isotope labeling for quantitative proteomics. Rapid Commun Mass Spectrom 2002;16(22):2115-23. [PubMed: 12415544]

49. Pan S, Gu S, Bradbury EM, Chen X. Single peptide-based protein identification in human proteome through MALDI-TOF MS coupled with amino acids coded mass tagging. Anal Chem 2003;75(6): 1316-24. [PubMed: 12659191]

50. Klisovic MI, Maghraby EA, Parthun MR, Guimond M, Sklenar AR, Whitman SP, Chan KK, Murphy T, Anon J, Archer KJ, Rush LJ, Plass C, Grever MR, Byrd JC, Marcucci G. Depsipeptide (FR 901228) promotes histone acetylation, gene transcription, apoptosis and its activity is enhanced by DNA methyltransferase inhibitors in AML1/ETO-positive leukemic cells. Leukemia 2003;17(2):350-8. [PubMed: 12592335]

51. Sures I, Gallwitz D. Histone-specific acetyltransferases from calf thymus. Isolation, properties, and substrate specificity of three different enzymes. Biochemistry 1980;19(5):943-51. [PubMed: 7356970]

52. Zhang L, Freitas MA, Wickman J, Parthun MR, Klisovic MI, Marcucci G, Byrd JC. Differential expression of histone post-translational modifications in acute myeloid and chronic lymphocytic leukemia determined by high-pressure liquid chromatography and mass spectrometry. J Am Soc Mass Spectrom 2004;15(1):77-86. [PubMed: 14698558]

53. Panyim S, Chalkley R. High resolution acrylamide gel electrophoresis of histones. Arch Biochem Biophys 1969;130(1):337-46. [PubMed: 5778650]

54. Pastink A, Berkhout TA, Mager WH, Planta RJ. Analysis of histones from the yeast Saccharomyces carlsbergensis. Biochem J 1979;177(3):917-23. [PubMed: 220954]

55. Waterborg JH, Harrington RE. Western blotting of histones from acid-urea-Triton- and sodium dodecyl sulfate-polyacrylamide gels. Anal Biochem 1987;162(2):430-4. [PubMed: 3605607]

56. Asou H, Tashiro S, Hamamoto K, Otsuji A, Kita K, Kamada N. Establishment of a human acute myeloid leukemia cell line (Kasumi-1) with 8;21 chromosome translocation. Blood 1991;77(9): 2031-6. [PubMed: 2018839]

57. Byrd JC, Marcucci G, Parthun MR, Xiao JJ, Klisovic RB, Moran M, Lin TS, Liu S, Sklenar AR, Davis ME, Lucas DM, Fischer B, Shank R, Tejaswi SL, Binkley P, Wright J, Chan KK, Grever MR. A phase 1 and pharmacodynamic study of depsipeptide (FK228) in chronic lymphocytic leukemia and acute myeloid leukemia. Blood 2005;105(3):959-67. [PubMed: 15466934]

58. Larizza L, Magnani I, Beghini A. The Kasumi-1 cell line: at (8;21)-kit mutant model for acute myeloid leukemia. Leuk Lymphoma 2005;46(2):247-55. [PubMed: 15621809]

59. Anderson JD, Lowary PT, Widom J. Effects of histone acetylation on the equilibrium accessibility of nucleosomal DNA target sites. J Mol Biol 2001;307(4):977-85. [PubMed: 11286549]

60. Dimitrov SI, Wolffe AP. Fine resolution of histones by two-dimensional polyacrylamide gel electrophoresis: developmental implications. Methods 1997;12(1):57-61. [PubMed: 9169195]

61. Sarg B, Helliger W, Talasz H, Koutzamani E, Lindner HH. Histone H4 hyperacetylation precludes histone H4 lysine 20 trimethylation. J Biol Chem 2004;279(51):53458-64. [PubMed: 15456746] 
62. Sarg B, Koutzamani E, Helliger W, Rundquist I, Lindner HH. Postsynthetic trimethylation of histone H4 at lysine 20 in mammalian tissues is associated with aging. J Biol Chem 2002;277(42):39195201. [PubMed: 12154089]

63. Warshel A, Naray-Szabo G, Sussman F, Hwang JK. How do serine proteases really work? Biochemistry 1989;28(9):3629-37. [PubMed: 2665806] 


\section{Ohr $4 \mathrm{hr} \quad 8 \mathrm{hr} \quad 12 \mathrm{hr} \quad 24 \mathrm{hr} \quad 48 \mathrm{hr}$}

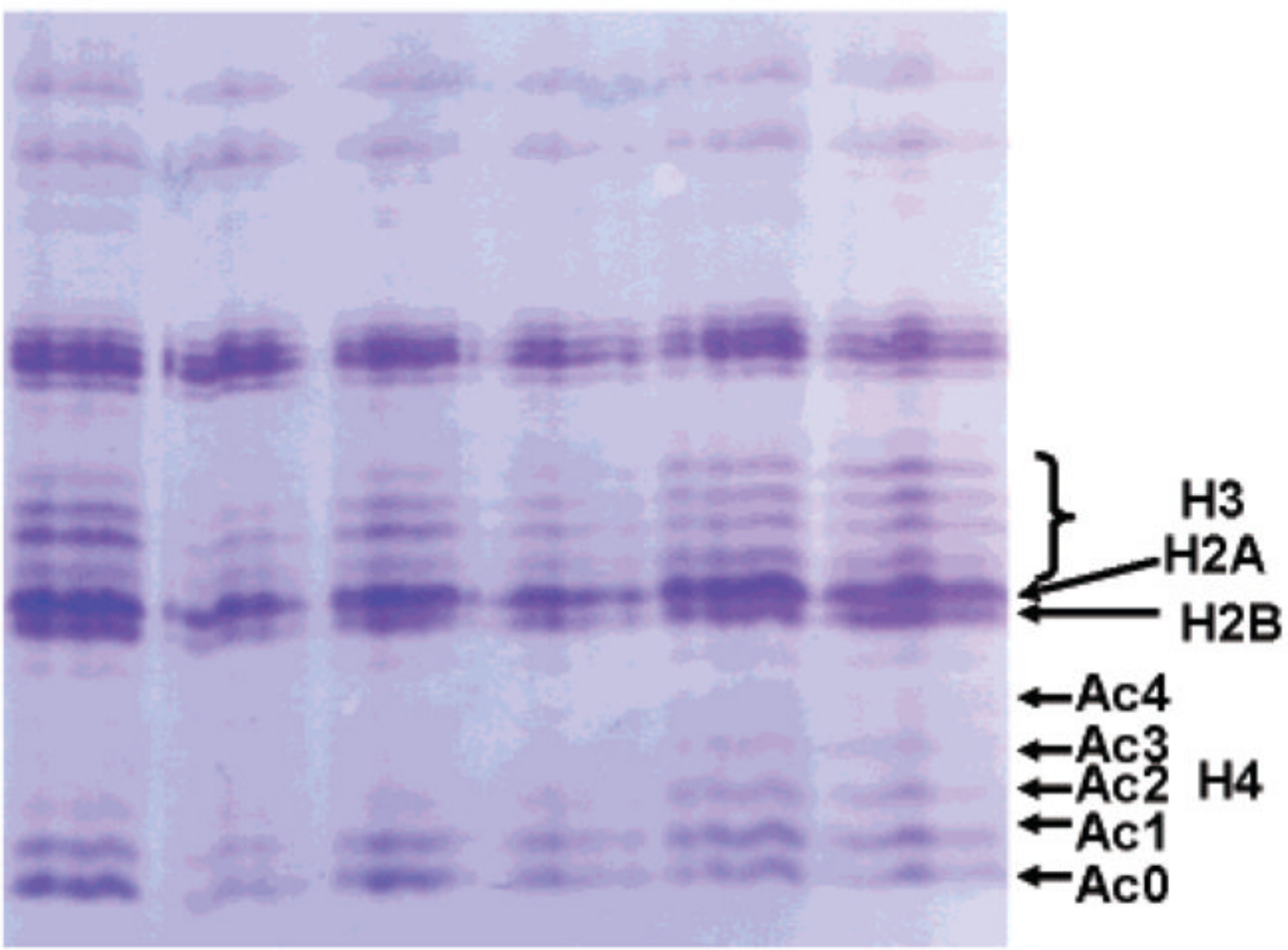

Figure 1.

AU-PAGE of histones (Lys- $\mathrm{D}_{0}+$ Lys- $\left.\mathrm{D}_{4}\right)$ treated with depsipeptide $(3 \mathrm{nM})$ for different treatment times. Two acetylations were observed at 0 and $4 \mathrm{~h}$. Between 0 and 3 acetylations were present in $\mathrm{H} 4$ when the treatment lasted for 8 and $12 \mathrm{~h}$. With 24 and 48-hour treatment, $0-4$ acetylations were observed in the protein. 


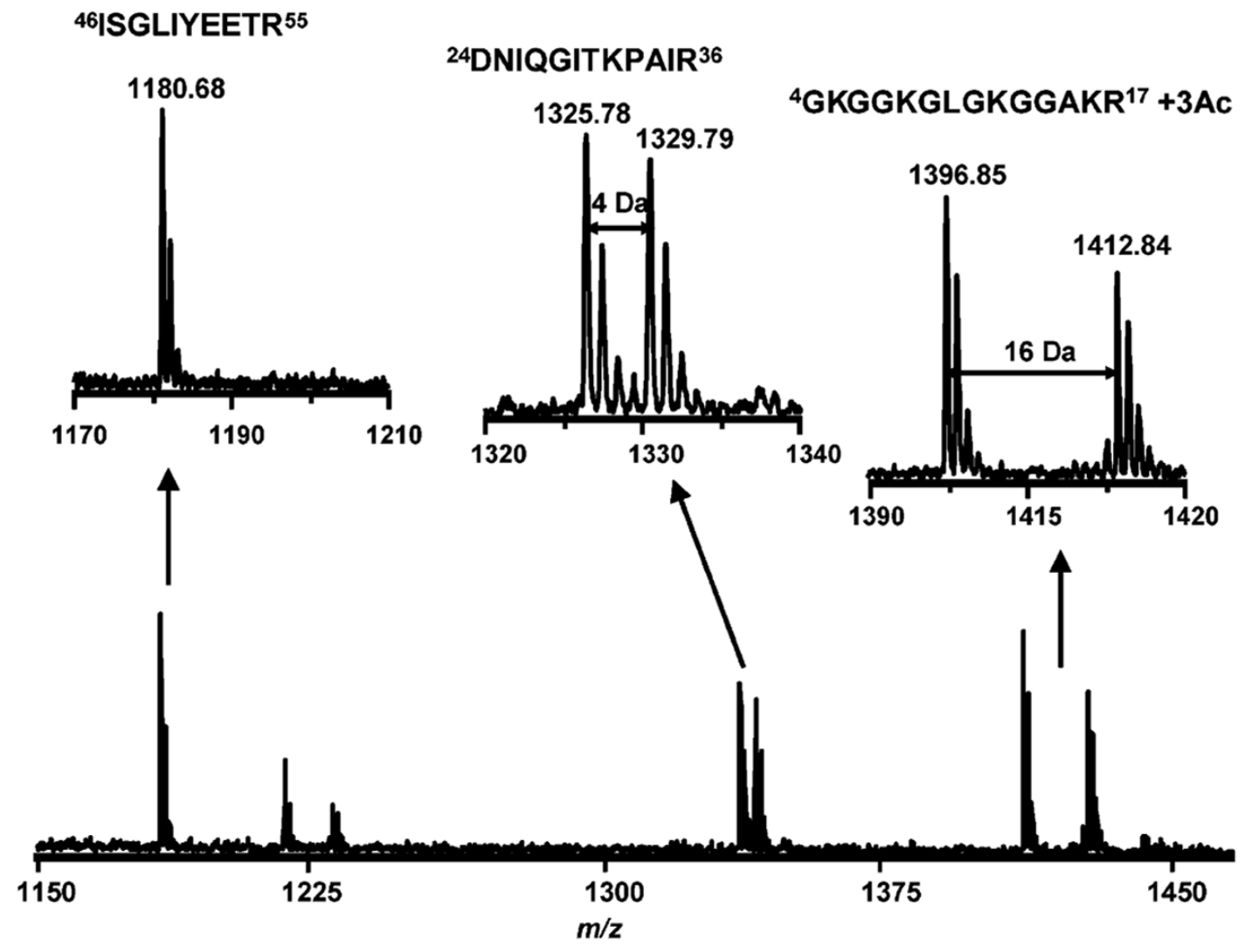

Figure 2.

Isotopic patterns observed in the AACM MALDI-TOF mass spectra. Mass shifts were observed as multiples $(N)$ of $4 \mathrm{Da}$, where $N$ is the number of the lysine residues in the peptide. 


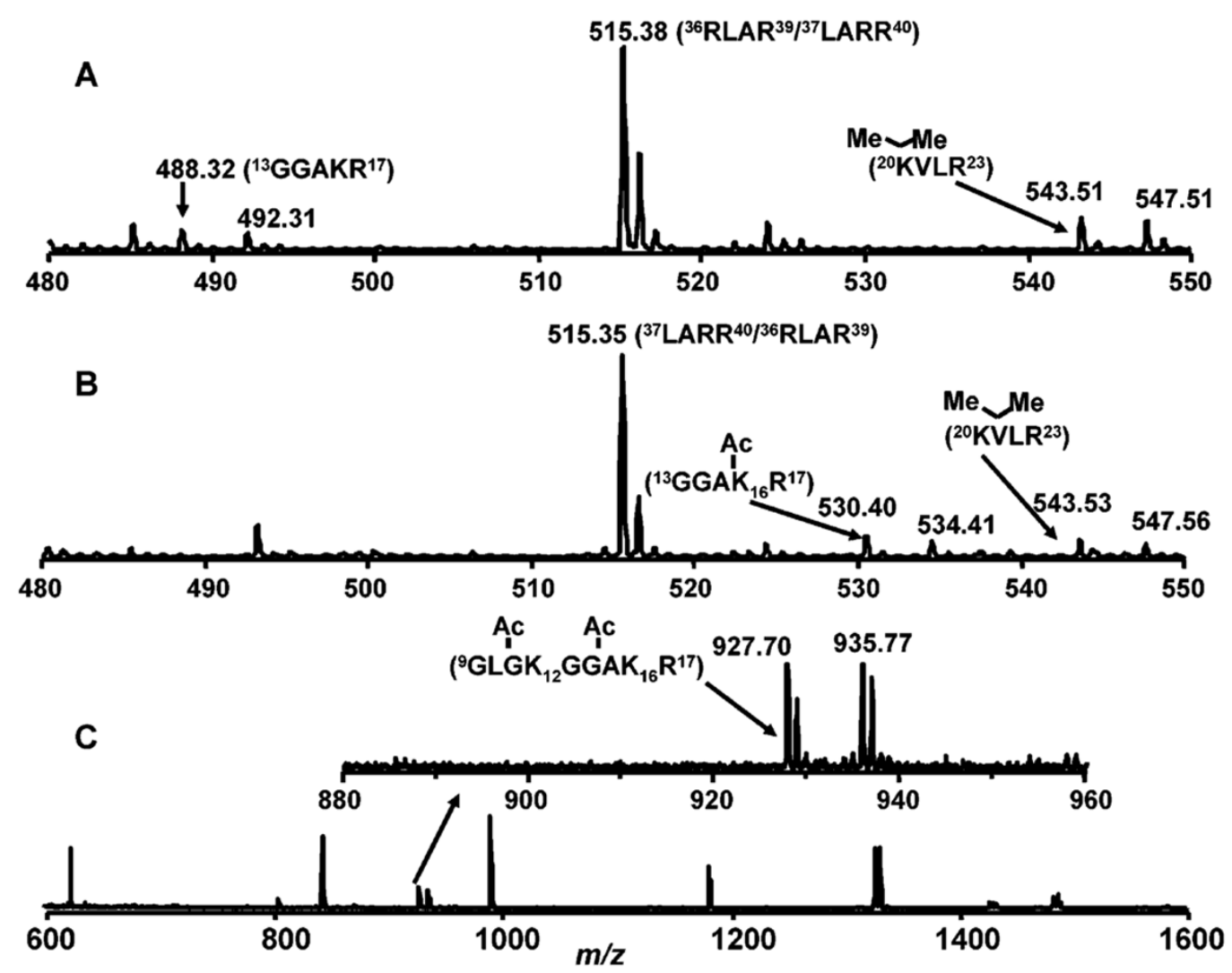

Figure 3.

MALDI-TOF mass spectra of the zero (A), mono (B), and diacetylated (C) isoforms of H4. (A) In the zero acetylated isoform, only dimethylation on K20 was observed. (B) The acetylated form of fragment 13-17 was observed, indicating the acetylation of K16. (C) The diacetylated isoform for fragment 9-17 was observed, indicating that H4 was initially acetylated on K16 and then K12. 

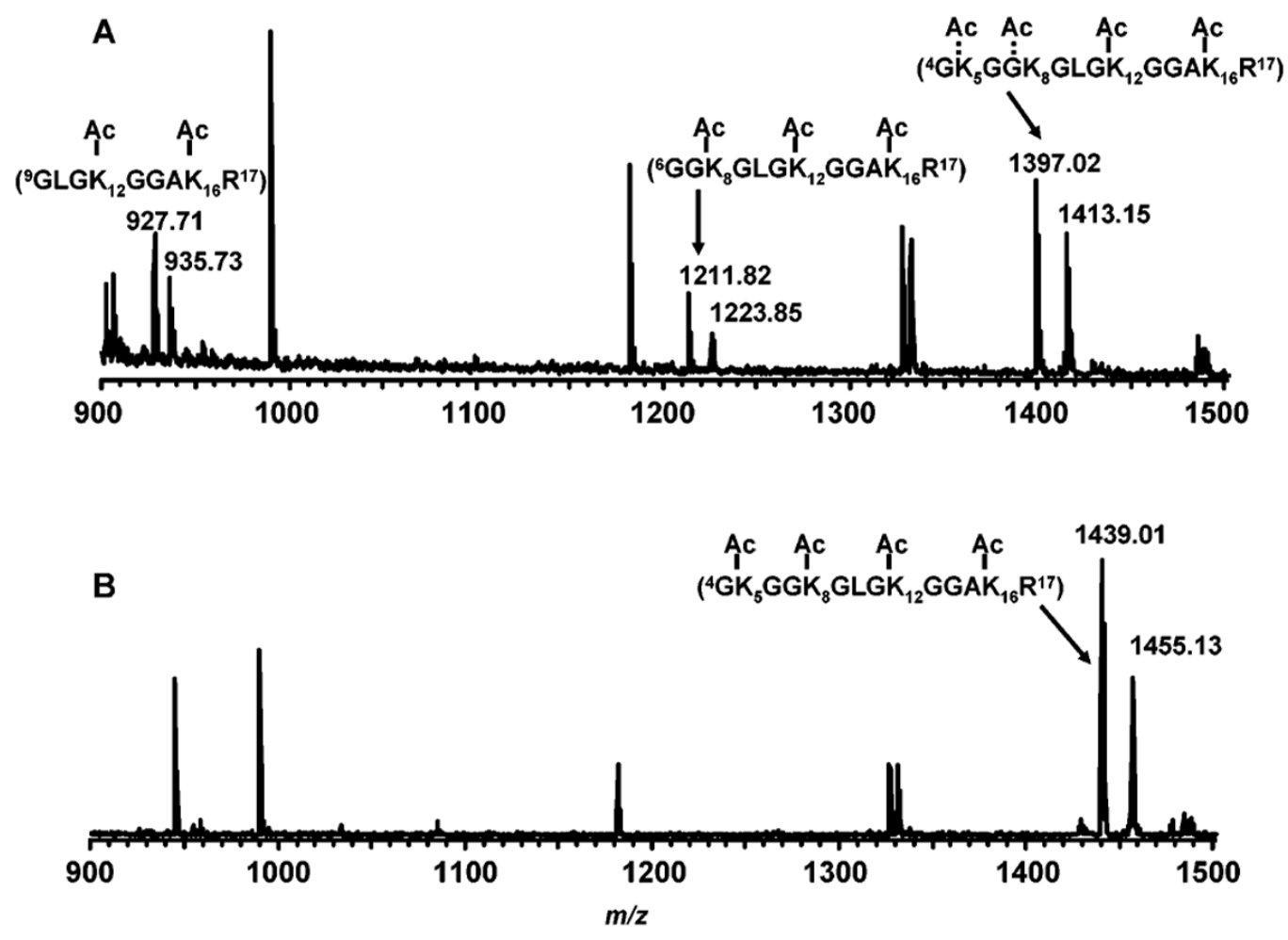

Figure 4.

MALDI-TOF mass spectra of triacetylated H4 (A) and tetracetylated H4 (B). (A) Triacetylated isofroms were observed for fragments 4-17 and 6-17, suggesting either K5 or K8 were acetylated following acetylation of K16 and K12. (B) K5, K8, K12, and K16 were all acetylated in the tetracetylated isoform. 


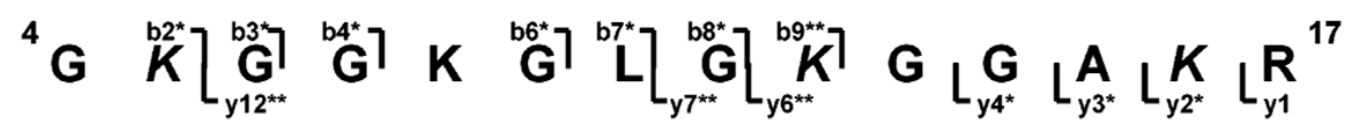

A

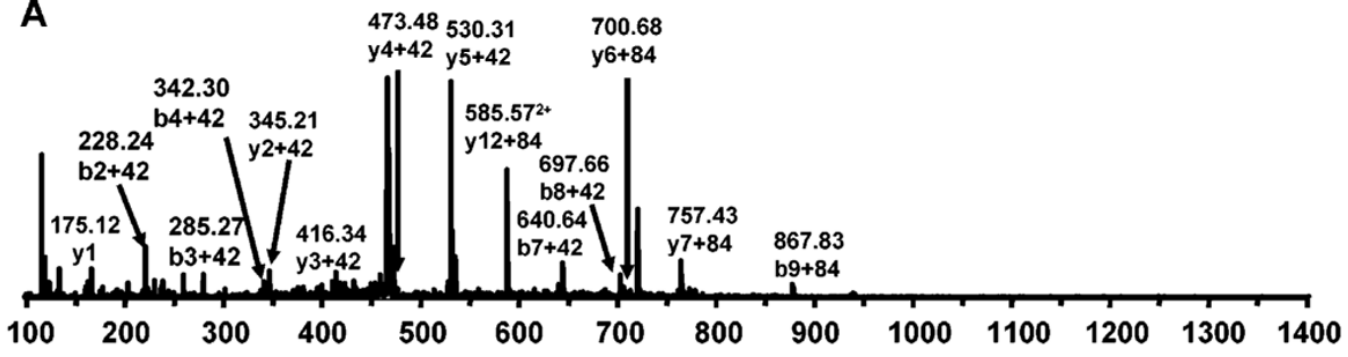

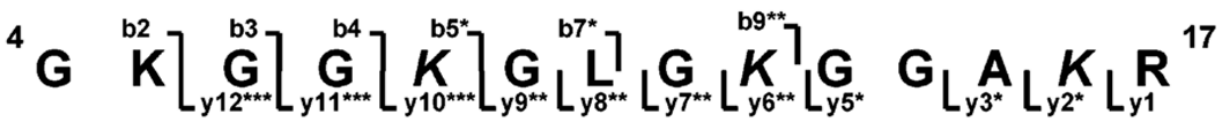

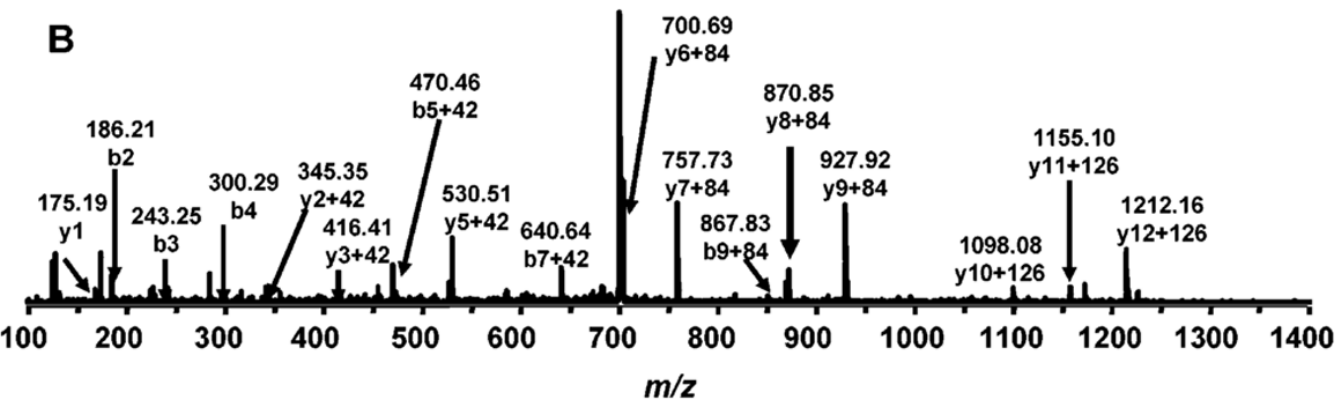

Figure 5.

MS/MS spectra of the triacetylated isoforms of the H4 peptide fragment 4-17. Ion bn*(yn*), $\mathrm{bn}^{* *}\left(\mathrm{yn}^{* *}\right)$, and $\mathrm{bn}^{* * *}(\mathrm{yn} * * *)$ represent mono-, di-, and triacetylated forms of these ions. Two modification patterns were observed: the acetylation on K5, K12, and K16 (A) and the acetylation on $\mathrm{K} 8, \mathrm{~K} 12$, and $\mathrm{K} 16$ (B). 


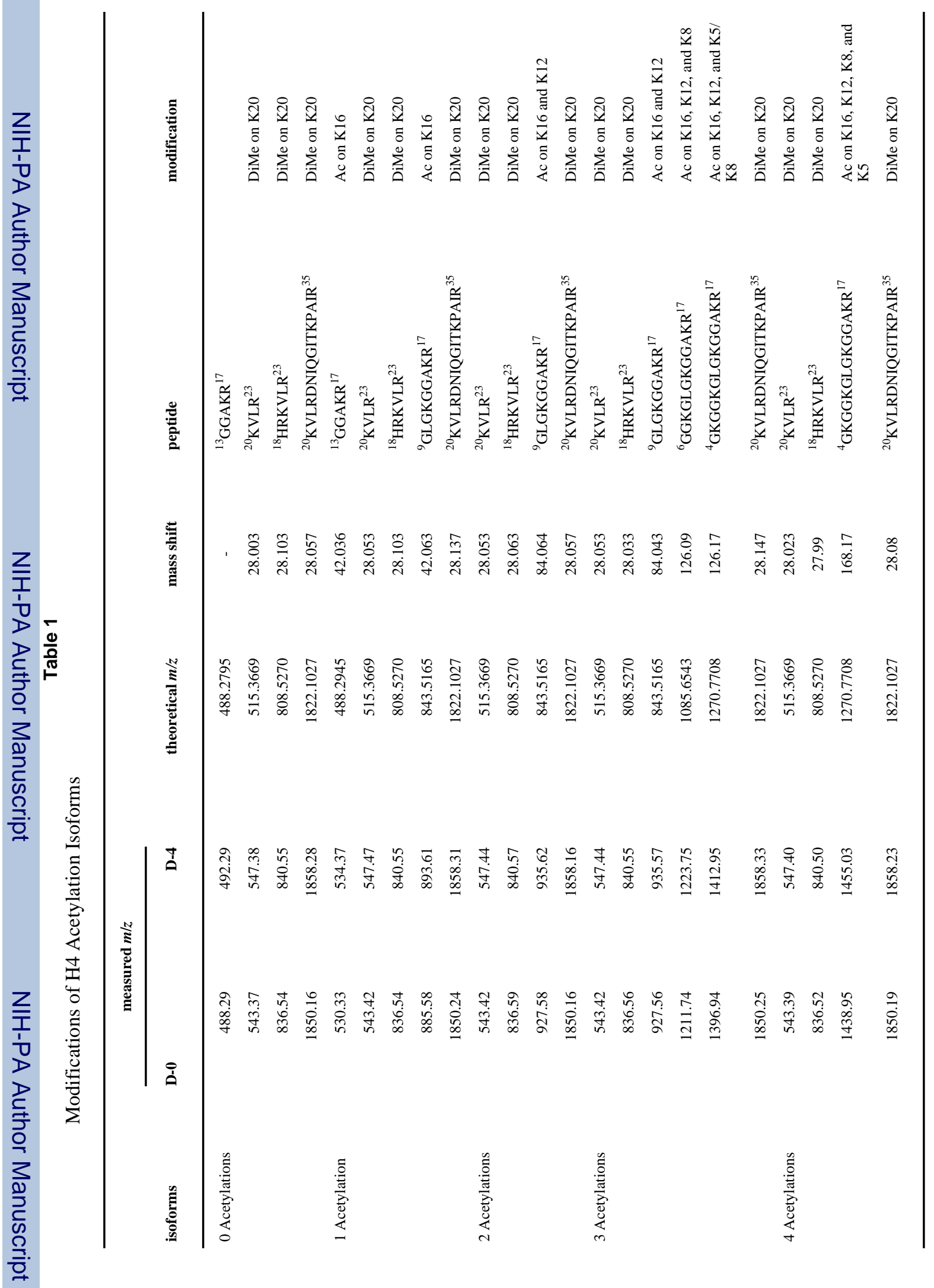

